\title{
FEM SIMULATION OF THE EXPERIMENTAL RESPONSE OF AAC MASONRY INFILLS IN RC FRAMES
}

\author{
Riccardo R. Milanesi ${ }^{1}$, Paolo Morandi ${ }^{2}$, Guido Magenes $^{2}$, and Baris Binici ${ }^{3}$ \\ ${ }^{1}$ IUSS Pavia \\ Via Ferrata 1, Pavia, Italy \\ riccardo.milanesi@umeschool.it \\ ${ }^{2}$ Dep. of Civil Engineering and Architecture of University of Pavia \\ Via Ferrata 1/3, Pavia, Italy \\ paolo.morandi@unipv.it, guido.magenes@unipv.it \\ ${ }^{3}$ Dep. of Civil Engineering of Middle East Technical University \\ Structural and Earthquake Engineering Laboratory, K2, Ankara, Turkey \\ binici@metu.edu.tr
}

Keywords: AAC masonry; masonry infill; FEM modeling; infill- structure interaction.

\begin{abstract}
Unreinforced masonry non-structural infills in RC structures are widely used in many countries. However, they are often designed with simplified methods which do not consider accurately their interaction with the structure. The limitation of their damage induced by earthquakes is of major interest for the prevention of extensive economic losses and possible threats to human lives. During the last decades several researches have been accomplished all around the world, and many different aspects have been investigated. The increasing interest on masonry infill is due to both the observation of unsatisfactory behaviour of infilled frame structures after real earthquakes and the difficulty to reach a widely scientifically recognized solution. Even if measures for the prevention of infill damage are to some extent included in modern seismic design code, an effective design procedure has not yet been achieved. The object of this study is to perform a numerical Finite Element Model simulation of a reinforced concrete frame specimen infilled with unreinforced Autoclaved Aerated Concrete masonry infill, in order to be able to study accurately the influence and the interaction of the non-structural wall to the reinforced concrete frame. A meso-modelling approach has been followed and the calibration has been performed according to the results of in-plane cyclic tests on single bay - single storey bare and infilled frames which have been carried out at the Department of Civil Engineering and Architecture of the University of Pavia [1, 3]. In order to obtain the parameters of the infill material, the numerical simulation has been performed, in first instance, with reference to tests of mechanical characterization and to inplane cyclic tests on load-bearing AAC masonry, similar to the one used for the infill [2,3]. The model has been validated via non-linear static analyses. Moreover, the change in moment and shear demands on the RC members of the frame due to the influence of the presence of the infill as respect to the bare frame condition has also been investigated.
\end{abstract}




\section{INTRODUCTION}

Unreinforced masonry is nowadays widely used in European countries as non-structural infill in reinforced concrete frame structures. Infills are commonly used as interior partitions, exterior enclosures and façade veneers to appropriately fulfill architectural needs. The current code provisions recognize the high seismic vulnerability of inherently brittle masonry infills; however, they often provide few recommendations for non-structural elements, being often insufficient, incomplete or not clearly defined for the specific prevention of infill damage. Field observations after major seismic events repeatedly point towards the high seismic vulnerability of masonry infills, not exclusively in older buildings but also in more recently designed RC frame structures $[4,5,6,7,8]$. In the last decades several earthquakes have occurred on the Italian territory and problems related to the performance of masonry infill countries, prone to seismic activity, have been identified (Figure 1).
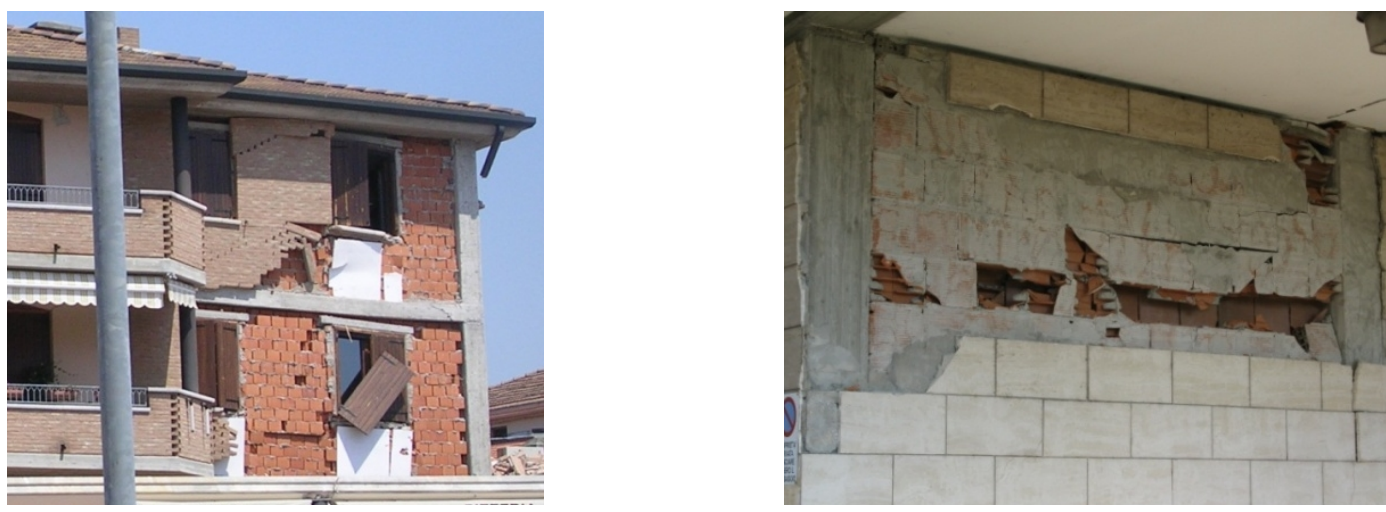

Figure 1: Masonry infill damage after Emilia earthquake in 2012 (Magenes, et al.) [6].

Furthermore, infills are usually considered only in terms of mass and dead loads; their stiffness and resistance contributes are often neglected. The limitation of the infill damage induced by earthquake is of major interest for the prevention of extensive economic losses and possible threats to human lives. During the last decades several researches have been accomplished worldwide, and many different aspects have been investigated through experimental $[9,10,11,12,13,14]$ and/or numerical $[15,16,17,18,19]$ studies.

The poor seismic behaviour of non-structural infills may not only be due to the inherent weakness of traditional unreinforced masonry but, in some cases, also caused by deficiencies in the design approach. On the other hand, a wide range of masonry types is available on the market and research is increasingly focused on possible improvements of the performance in seismic conditions through the introduction of new products and innovative construction techniques.

The use of Autoclaved aerated concrete (AAC) blocks for both structural and nonstructural purposed is increasing. Its main advantages are the lightness, the excellent thermal insulation and fire resistance. However, research of AAC masonry infill is not widespread yet, therefore some experimental campaigns combined with adequate numerical research are necessary.

The object of this study is to perform a numerical Finite Element Model simulation of a $\mathrm{RC}$ frame specimen infilled with unreinforced AAC masonry infill in order to be able to study accurately the influence and the interaction of the non-structural wall to the $\mathrm{RC}$ frame. 


\section{CURRENT EUROPEAN SEISMIC CODE PROVISIONS}

According to Eurocode 8 [20], structures in seismic regions have to be designed and constructed such that fundamental performance requirements associated with adequate degrees of reliability related to life safety and damage limitation are satisfied. Consequently, ultimate limit states (ULS), associated with no-collapse or life safety requirements, have to be verified at a reference design seismic action for which a reference return period of $T_{U L S}$ is defined in the National Annex of each country. Eurocode 8 [20] states that the structures shall be designed and constructed to withstand the ULS seismic action without local or global collapse, thus retaining its structural integrity and a residual load bearing capacity after the seismic event. The verification of damage limit state (DLS) is required for the corresponding seismic action with a return period $T_{D L S}$, having a larger probability of occurrence than the design seismic action. Structures shall be designed and constructed to withstand the DLS seismic action without the occurrence of damage and the associated limitations of use. The design procedure to be followed according to Eurocode 8 [20] provisions for the seismic design of RC structures is illustrated in Figure 2.

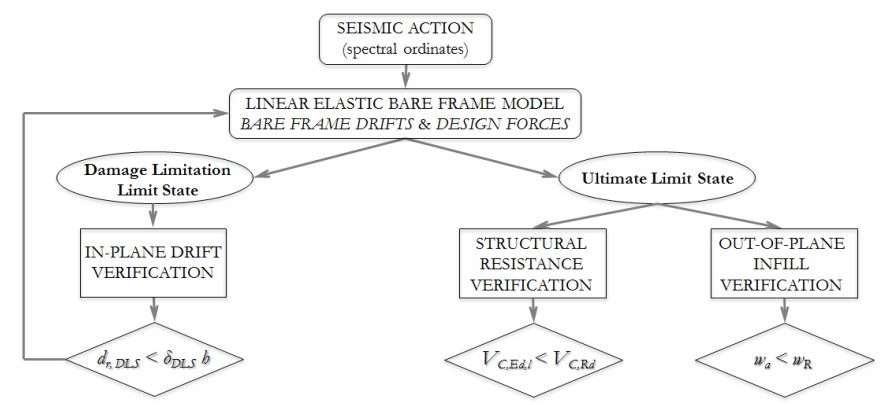

Figure 2: Current design procedure for masonry infilled RC structures according to Eurocode 8 [20].

The damage limitation requirements, according to Eurocode 8 [20], are considered satisfied if the inter-storey drift $d_{r, D L S, j} / h_{j}\left(d_{r, D L S, j}\right.$ representing the inter-storey displacement for storey $j$ induced by the damage limitation seismic action and $h_{j}$ the storey height) do not exceed the inter-storey drift limitation $\delta_{D L S}$ (Equation 4) equal to $0.50 \%$, for buildings with brittle non-structural elements fixed such that they do not interfere with structural deformations, and equal to $1.0 \%$ in case of structures without non-structural elements.

No further specifications are provided referring to the definition of brittle and ductile nonstructural elements. Probably in most cases masonry infills will intuitively be classified as brittle.

At the ULS, the safety verification has to be accomplished in terms of resistance to seismic action effects for both structural and non-structural elements. In particular, for non-structural elements that might, in case of failure, cause risk for human life or affect the main structure of the building or services of critical facilities, the verification of resistance for the design seismic action is foreseen and a simplified procedure is proposed for the evaluation of the seismic force acting on the non-structural element. Thus, the effects of the seismic action may be determined applying a horizontal force $F_{a}$, acting at the centre of mass of the non-structural element in the most unfavourable direction, Structural inter-storey drift limitation.

For the local effects, the Eurocode 8 [20] prescribes to assume the critical length equal to the total height for columns at the ground floor or in case the infill is in full column with the column only on one side (Figure 3 ). 

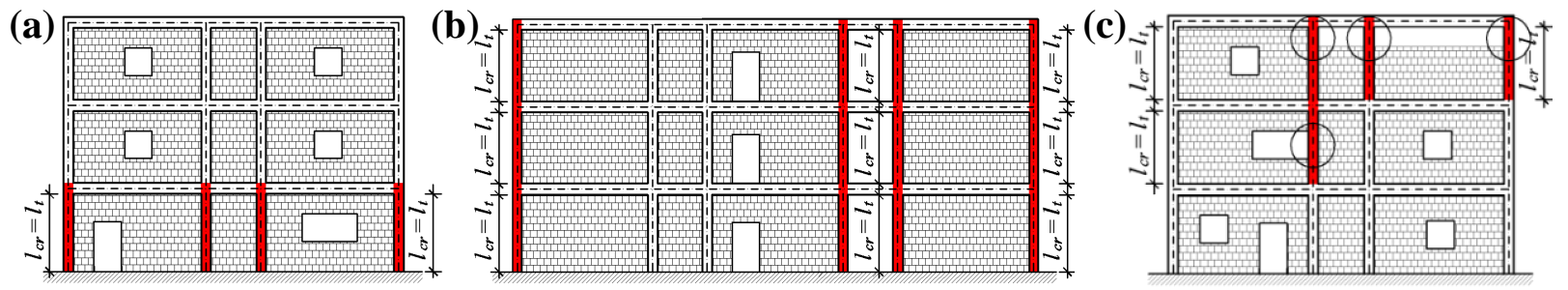

Figure 3: Critical length of the columns (a) in the ground floor, (b) in full contact with the infill on one side, and (c) in partial contact with the infill [31].

The contact length $l_{c}$ of the column, over which the equivalent diagonal strut force of the infill acts on the column causing a local pressure $f_{t}$ and introducing a concentration of forces (Figure $4 \mathrm{a}$ ), should be verified in shear for the demand $V_{C, E d, l}$ evaluated as the smaller of the following two shear forces (Equation 1):

- the shear demand $V_{C, E d, w}$ equal to the horizontal component $F_{w, h o r}$ of the infill, that can be assumed equal to the strength of the panel (Equation 2);

- the shear demand $V_{C, E d, M}$ determined following the capacity design principle (Equation 3 ), assuming that the flexural column capacity develops at the ends of the contact length $l_{c}$, as shown in Figure $3 \mathrm{~b}$.

$$
\begin{gathered}
V_{C, E d, l}=\min \left(V_{C, E d, w} ; V_{C, E d, M}\right) \\
V_{C, E d, w}=\min \left(f_{v 0} t_{w} l_{w} ; \frac{f_{t} t_{w} l_{w}}{b}\right) \\
V_{C, E d, M}=\gamma_{R d} \frac{2 M_{C, R d}}{l_{c}}
\end{gathered}
$$

a)

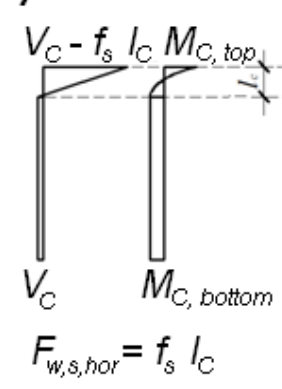

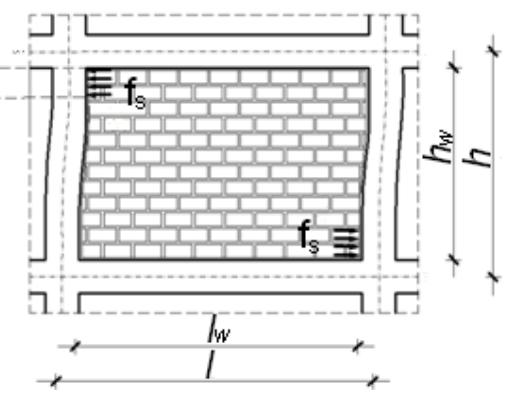

b)

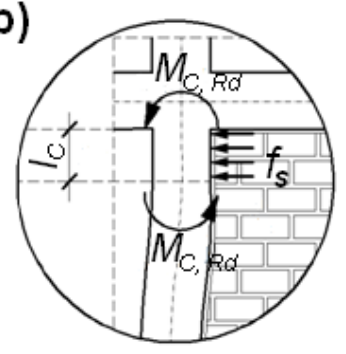

Figure 4: Local effects on an infill adjacent column [31].

\section{DESCRIPTION OF THE EXPERIMENTAL CAMPAIGN}

In the late '90s, some experimental tests on different weak clay masonry infills in reinforced concrete frames have been executed in an extensive experimental research performed by Calvi and Bolognini [1]. Full-scale, single-storey, single-bay frame specimens were designed according to modern seismic code provisions and subjected to in-plane and out-ofplane tests. The experiments consisted in a cyclic pseudo-static in-plane test up to $3.6 \%$ drift for the bare frame, also vertical constant load of $400 \mathrm{kN}$ was applied at the top of each column. Figure 3 illustrates the dimensions and the reinforcement of the frame (5a), the point of application of the loads during the tests $(5 \mathrm{~b})$ and the Force-Displacement curve of the bare frame obtained from the in-plane test $(5 \mathrm{c})$. 
(a)

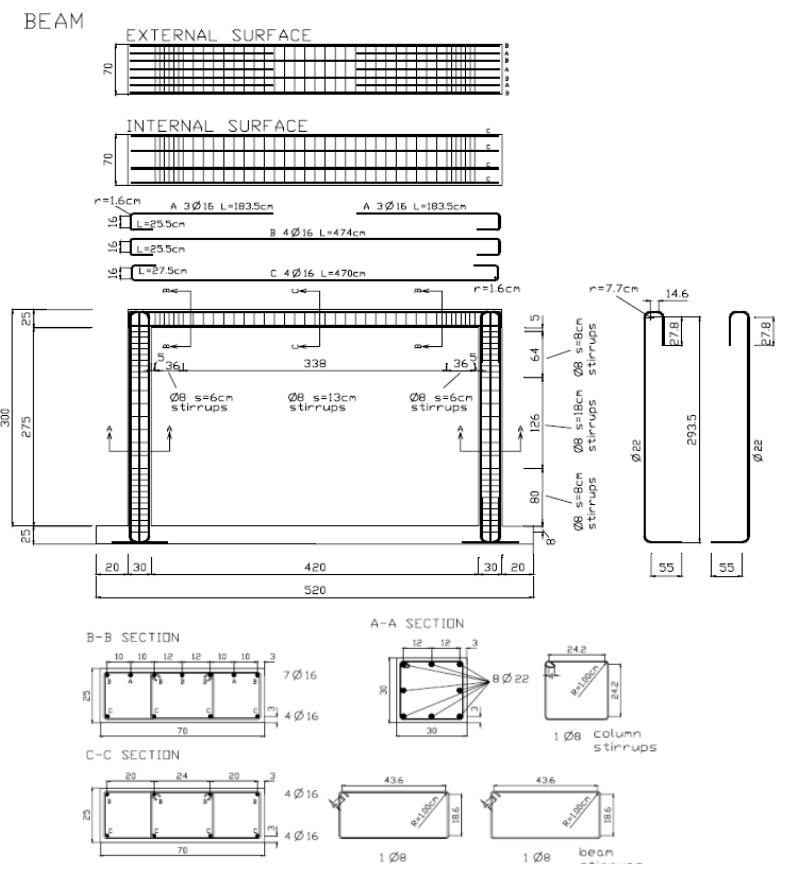

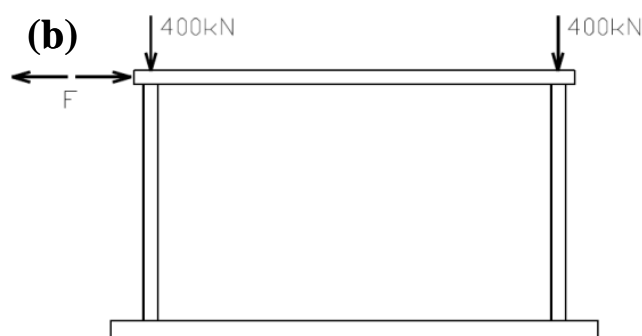

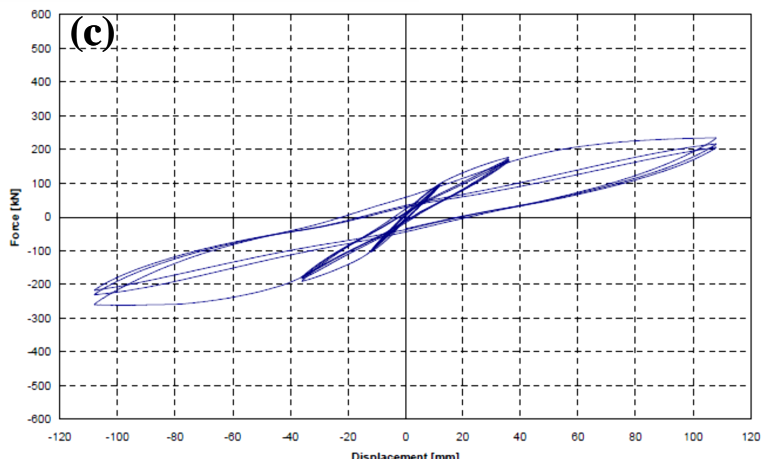

Figure 5: (a) Dimensions and reinforcement of the RC frame; (b) Application points of the loads during the test; (c) Force-Displacement curve of the bare frame obtained from in-plane cyclic pseudo-static test.

In 2006 several tests on AAC masonry infills have been conducted by Penna and Calvi [3], using the same RC frames of the research by Calvi and Bolognini [1]. Different AAC infills were tested: unreinforced, reinforced with a RC mid-height beam, reinforced with steel bars in the bed joints and with and without opening.

For the aim of this study, only in-plane tests on the bare frame and the unreinforced AAC infill have been considered. In Figure 6 the cracking pattern at the end of the selected AAC infill (6a) and the corresponding Force-Displacement curve (6b) are reported; the specimen has been tested up to a drift of $1.2 \%$.

(a)

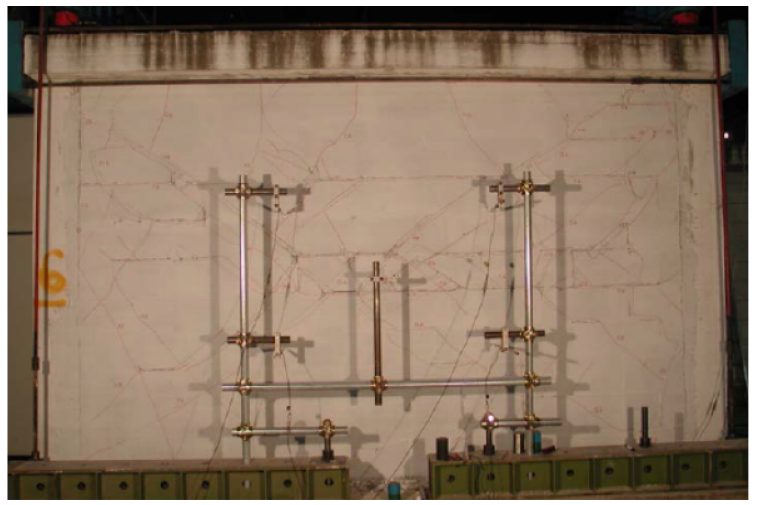

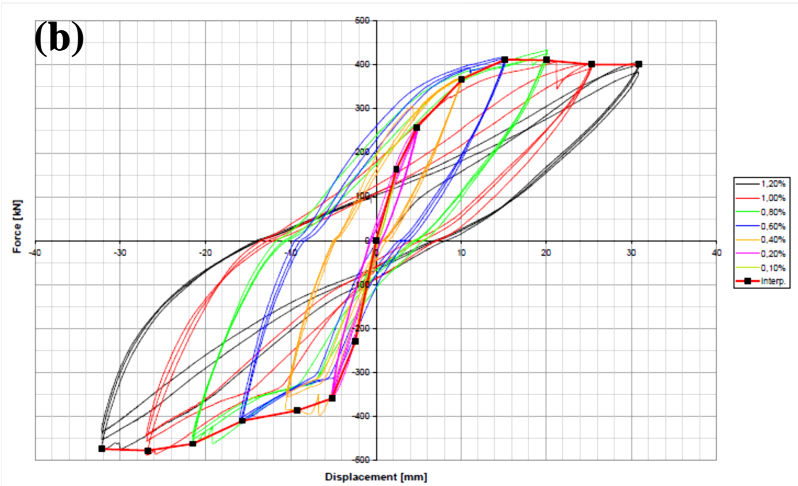

Figure 6: Unreinforced AAC infill. Crack pattern (a) and Force-Displacement curve (b) [3].

Penna and Calvi [3] have additionally carried out experiments of mechanical characterization on AAC units, hardened mortar and masonry wallets; some of them, in particular the vertical and the horizontal compression tests and diagonal compression tests (Figure 7a) on the masonry specimens, have been used in the present work to calibrate the numerical model. 
A type of AAC masonry similar to the one tested as infill has also been investigated by Costa et al. [2], where in-plane cyclic tests, with cantilever boundary conditions, on load bearing masonry piers were performed at the University of Pavia on 4 panels with different dimensions and diverse applied vertical loads (Figure 7b). All the specimens were $2.75 \mathrm{~m}$ height and $0.30 \mathrm{~m}$ thick, however, the first 2 specimens had the same length $(1.5 \mathrm{~m})$ but they differed for the vertical load applied which was $200 \mathrm{kN}$ and $300 \mathrm{kN}$, respectively. In the last 2 experiments the same vertical load of $300 \mathrm{kN}$ was applied, however the panels had different width $(3.0 \mathrm{~m}$ and $4.5 \mathrm{~m})$. The in-plane response of some of the first two experiments have also been used to better calibrate the finite element model.

(a)

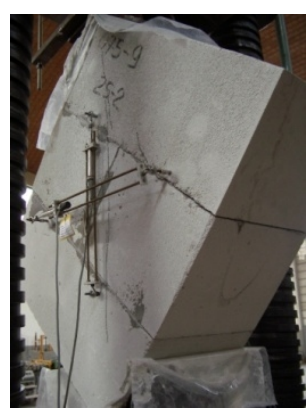

(b)

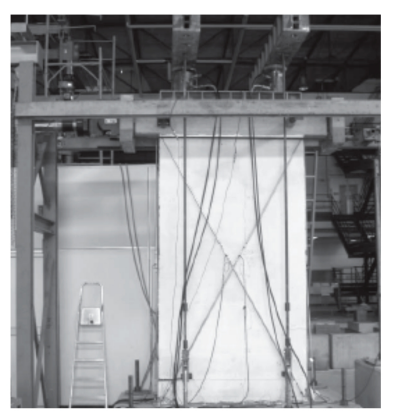

Figure 7: (a) Diagonal compression test on AAC masonry [3]; (b) Setup of the test conducted on the load bearing AAC wall [2].

\section{DESCRIPTION OF THE FINITE ELEMENT MODEL}

Several different modeling approaches have been developed by the passing of the decades. Crisafulli et al. [21] classified the model used for RC infilled structured into two groups: micro-model, also called local models, where the structure is divided into numerous elements to take into account the local effects in details; and the macro-models, also called simplified models, they are based on a physical understanding of the behaviour of the infill panel. However, the classification proposed by Crisafulli might not be enough detailed; Lourenço [22] proposed to classify the micro model depending on the level of refinement. The masonry can be represented as an homogenous material, sometimes, these models are defined as "mesomodels". It is also possible to model the masonry as composed by masonry unit continuous elements and interface elements as mortar joints. A third approach consists in modeling the masonry as two-phase materials; masonry units and mortar joints are modeled as two different continuous elements and their mechanical behaviour of is specified separately.

For the present study a meso-model has been used with the aim on TNO Diana software [23].

\subsection{Crack models}

Finite element approaches for the modeling of a masonry infill in a reinforced concrete frame may usually refer to two well known crack models: discrete and smeared (Roots [24]). The discrete crack criterion appears to be able to reach more detailed results, however, it suffers from two major drawbacks: it necessitates a continuous change in nodal connectivity, which unfits the nature of the finite element displacement method and force the crack to follow a predefined path along the element edges, which baffles the accuracy of the approach. In the smeared crack criterion the materials are instead idealized to be a homogeneous continuum. The smeared crack criterion can be categorized into a fixed and rotating smeared crack approach. 
In the present work, the total strain crack model has been used, originally proposed by Vecchio and Collins [25]. The strain vector $\boldsymbol{\varepsilon}_{\mathbf{x y z}}$ in the element coordinate system " $x y z$ " is updated at each step using the strain increment $\boldsymbol{\varepsilon}_{\mathbf{x y z}}$ according to Equation 4 .

$$
{ }^{t+\Delta t_{i+1}} \varepsilon_{x y z}={ }^{t} \varepsilon_{x y z}+{ }^{t+\Delta t_{i+1}} \Delta \varepsilon_{x y z}
$$

The strain vector in the element coordinates "xyz" is transformed to strain vector in tne crack directions "nst" with the strain transformation matrix $\mathbf{T}$.

$$
{ }^{t+\Delta t_{i+1}} \varepsilon_{n s t}=T^{t+\Delta t_{i+1}} \varepsilon_{x y z}
$$

The strain transformation matrix $\mathbf{T}$ is fixed upon cracking in the fixed approach, whereas it depends on the current strain vector in the coaxial rotating crack approach:

$$
T=T\left({ }^{t+\Delta t_{i+1}} \varepsilon_{x y z}\right)
$$

Both in the fixed and in the rotating approach, the compressive stress is evaluated in the rotated coordinate system. However, in the fixed approach case, the behaviour in compression is evaluated in the fixed coordinate system which defines the direction of cracks. The constitutive model is formulated in the cracked coordinate system that is given by Equation 7.

$$
{ }^{t+\Delta t_{i+1}} \sigma_{n s t}=\sigma\left({ }^{t+\Delta t_{i+1}} \varepsilon_{n s t}\right)
$$

Updated stress vector in the element coordinate system is finally given by Equation 8 .

$$
{ }^{t+\Delta t_{i+1}} \sigma_{x y z}=T^{t+\Delta t_{i+1}} \sigma_{n s t}
$$

Moreover, in the fixed crack model it is necessary to model the degradation of the shear behaviour along the crack whereas, in the rotating crack model, the direction of the principal stress is assumed to coincide with the direction of the principal strains; in fact, no shear strain occurs perpendicular to the cracking and only two normal stress components may be calculated using stress-strain models.

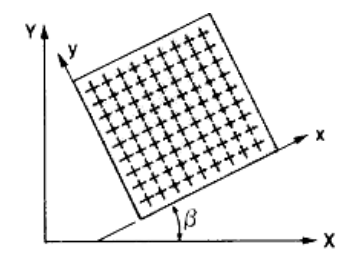

(a) Element in Global System

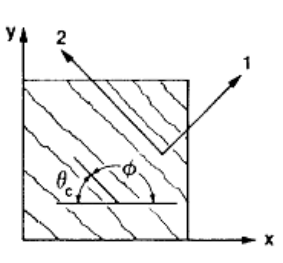

(b) Concrete Component

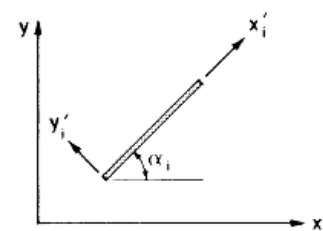

(c) Reinforcement Components

Figure 8: Reference coordinate system for elements [22].

In the present work both the concrete and the AAC masonry infill have been modeled using the smeared total strain rotating crack model.

\subsection{Elements used in the FEM}

Both the frame and the masonry infill have been modeled with an eight-node quadrilateral isoparametric plane stress element (Figure 9a) based on quadratic interpolation and Gauss integration. The frame-infill interface were modeled using six-node interface elements (Figure $9 b)$. 
(a)

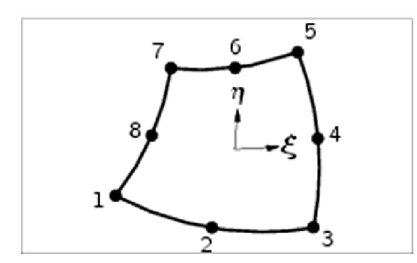

(b)

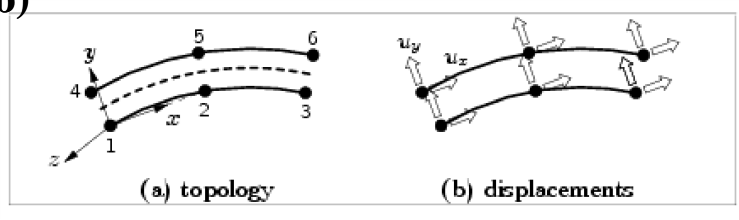

Figure 9: (a) 8-node quadrilateral isoparametric plane stress element; (b) Frame-infill 6-node interface element.

\subsection{Material constitutive models}

The same constitutive model has been used for the concrete of the frame and for the AAC masonry infill. A parabolic behaviour under compression has been assumed for the concrete and the AAC masonry (Figure 10a) and the compressive strength, along with the compressive fracture energy, has been defined. The "crack bandwidth" $(h)$ which is contingent on the element size and the type of element used has been computed automatically by Diana, and it avoids the "size effect". The reduction of the compressive strength due to lateral cracking has been considered according to the relationship proposed by Vecchio and Collins [25] (Figure 10b). In addition, the increase of the compressive strength due to lateral confinement has been taken into account, using the model proposed by Selby and Vecchio [26].

The tensile behaviour has been idealized according to the model developed by Hordijk [27] (Figure 10c). The tensile strength $f_{c t m}$ has been computed according to Eurocode 2 [28], and the Mode-I fracture energy has been considered according to CEB-FIP Model Code 2010 [29] (Equation 9).

$$
G_{F}^{I}=0.70 \cdot 73 f_{c m}^{0.18} \div 1.30 \cdot 73 f_{c m}^{0.18}
$$

where $f_{c m}$ is the mean value of concrete cylinder compressive strength. The minimum value of the interval of the Mode-I fracture energy has been assumed. As an alternative, an elasticbrittle tensile constitutive model has also been used.

For the reinforcing steel, the Von Mises yield criterion was adopted, with a bilinear stressstrain curve in uniaxial tension. The reinforcement steel bars have been considered as "embedded reinforcement" which do not have degrees of freedom on their own but add stiffness to the finite element model. In this modeling technique, reinforcing bars are assumed not to occupy any space or mass in the finite element model and the addition of embedded bars do not provide any weight to the mother element. The strains of the reinforcement are computed from the displacement field of the mother elements assuming perfect bond with the surrounding material.

The frame-infill interface elements employ a Coulomb Friction criterion (Figure 10d). The linear normal and tangential stiffness of the interface elements were assumed to be equal. The cohesion $c$ and the friction coefficient $\tan \Phi$ were computed from initial shear tests according to EN 1052-3 [30]. This model assumes that a gap forms if the tensile strength is exceeded.
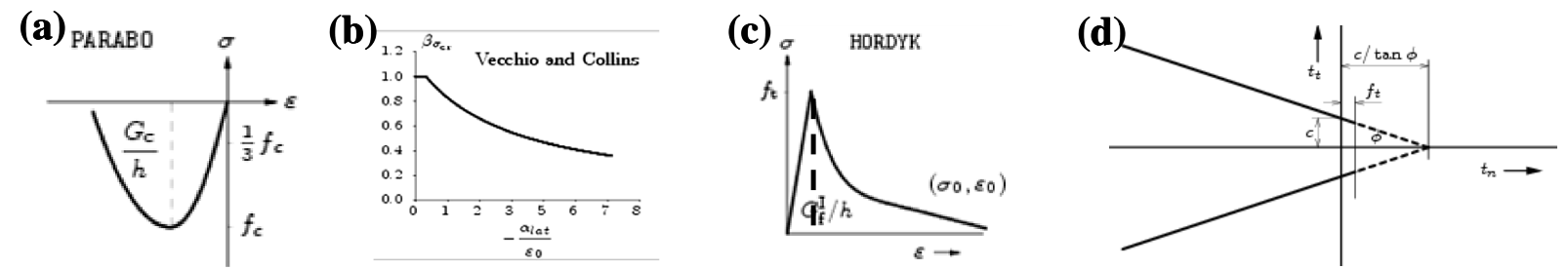

Figure 10: (a) Parabolic compressive behaviour which can be used in rotating crack model; (b) Vecchio and Collins relationship for reduction factor due to lateral cracking; (c) Hordijk tensile constitutive law which can be used in rotating crack model, brittle tensile constitutive law in dashed line; (d) Coulomb friction criterion with tensile strength limit. 


\section{CALIBRATION OF THE AAC MASONRY ON THE TESTS OF CHARACTERIZATION AND ON THE IN-PLANE CYCLIC TESTS OF LOAD- BEARING PIERS}

In order to evaluate the mechanical characteristics of the AAC masonry, different type of tests on small specimens were performed in the study on the AAC infills by Penna and Calvi [3]; for the sake of this work, the results of the vertical, the horizontal and the diagonal compressive strength tests have been taken into consideration. In addition, in order to investigate the seismic response of load-bearing masonry piers, different in-plane cyclic tests have been executed in the framework of the research conducted by Costa et al. [2].

Some of the most relevant results of the monotonic push-over analyses obtained by the FEM modeling calibrated on the results of the tests of characterization and of the in-plane cyclic tests on masonry piers are hereafter presented.

The masonry studied was composed by $30 \mathrm{~cm}$ thick AAC unit and both horizontal and vertical thin layers of mortar.

\subsection{Calibration of the AAC masonry on the vertical and horizontal compression tests}

The Figure 11 illustrates some phases of the vertical and the horizontal compression tests on masonry wallets . A mean value of about 2.0 MPa was found for the compressive strength of the wallets and the values of deformations were measured through linear potentiometers.

(a)

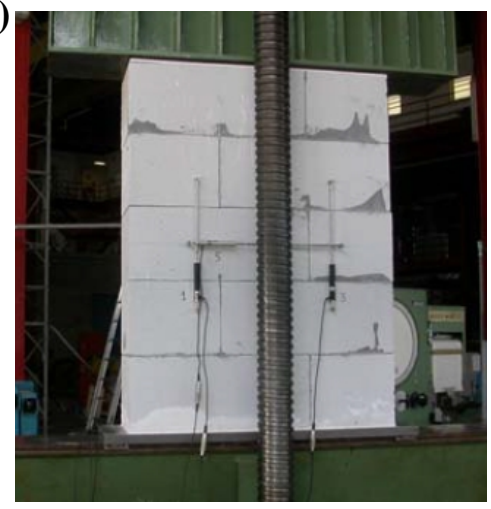

(b)

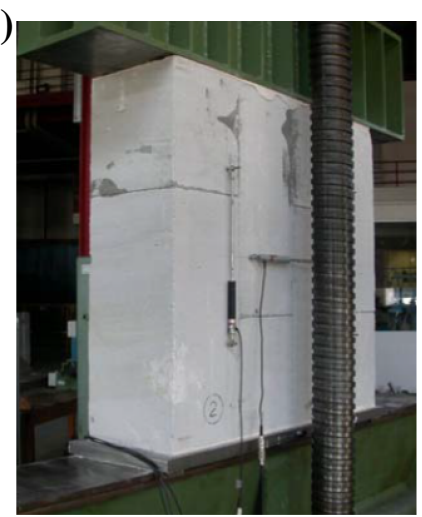

Figure 11: Tests on AAC masonry carried out at the University of Pavia [3]: (a) vertical compression test; (b) horizontal compression test.

The masonry has been modeled as an isotropic homogenous material. The elastic-brittle and the Hordijk constitutive models for the tensile behaviour of the masonry have been used. Figure 12 reports the comparison between the experimental tests and the FEM analyses in terms of stress-strain relationship (Figure 12a for the vertical and Figure 12b for the horizontal compression). For both vertical and lateral compression three cyclic tests have been performed, in Figure 12 their stress-strain curves are also reported. The results appear to be in good agreement, although the peak stress is not perfectly attained in both the cases (vertical and horizontal compression). Moreover, the two laws used for modeling the tensile behaviour of the material have provided similar results in the case of the vertical compression tests but a different deformation capacity for the case of the horizontal compression tests, being the Hordijk model more conservative. 
(a)

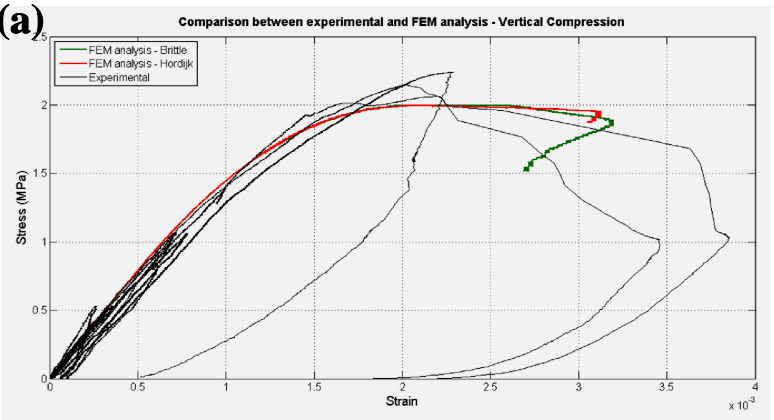

(b)

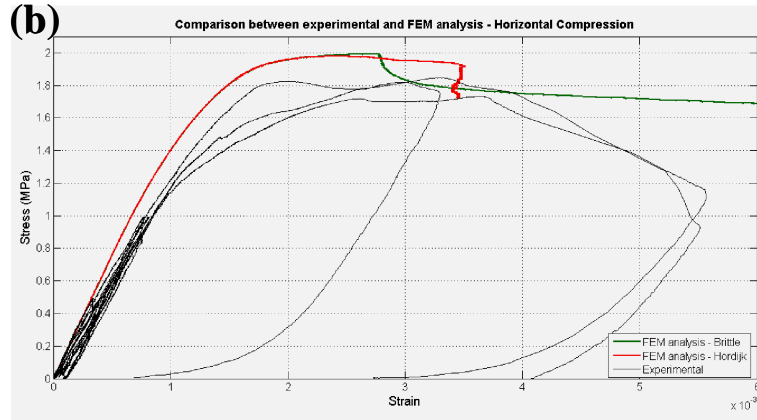

Figure 12: Comparison between experimental and FEM analysis: (a) vertical compression; (b) horizontal compression.

\subsection{Calibration of AAC masonry on the diagonal compression tests}

Seven monotonic diagonal compression tests on masonry wallets were carried out (Figure 13a). The average tension strength obtained was of about $0.28 \mathrm{MPa}$.

A comparison between experimental, Hordijk and elastic-brittle tensile behaviour is shown in Figure 13b. The parameters of these analyses are the same used for the comparison with the results of the vertical/diagonal compression tests. The Hordijk tensile behaviour presents a better accuracy in the descending branch, whereas the brittle model appears to predict slightly better the peak and its location in the load-displacement coordinates. In both the cases the stiffness and the obtained ultimate displacement have found to be accurate. The Hordijk tensile behaviour has been preferred to the elastic-brittle one. Table 1 summarizes the obtained maximum load. Figure 14 displays the principal stresses in the specimen at different steps, with the results in good agreement with the cracking pattern of the masonry wallet.

\begin{tabular}{lcc}
\hline & Max Load & Horizontal displacement at peak \\
\hline Experimental average & $115.1 \mathrm{kN}$ & $0.281 \mathrm{~mm}$ \\
Elastic-brittle constitutive law in tension & $116.4 \mathrm{kN}$ & $0.311 \mathrm{~mm}$ \\
Hordijk constitutive law in tension & $118.0 \mathrm{kN}$ & $0.315 \mathrm{~mm}$ \\
\hline
\end{tabular}

Table 1: Comparison of the peak values between experimental results and the one obtained from the FEM analysis with the two tensile constitutive models.
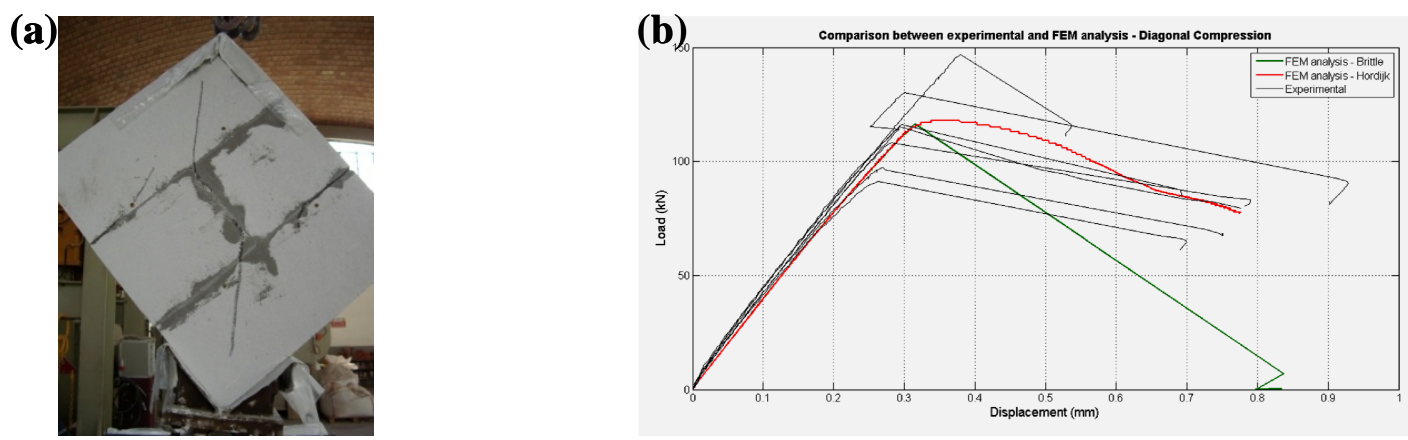

Figure 13: Comparison between experimental and FEM analysis:(a) vertical compression; (b) horizontal compression. 

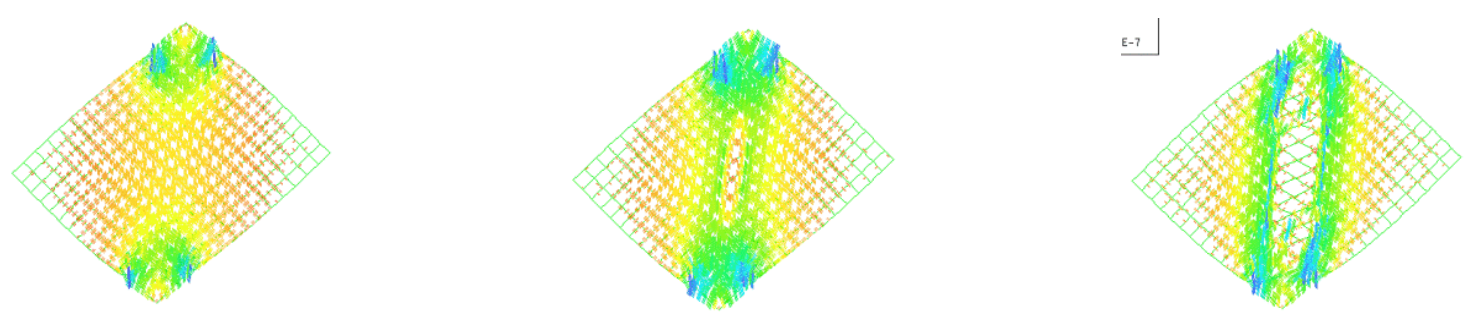

Figure 14: Principal stresses at different steps.

\subsection{Calibration of AAC masonry on the in-plane cyclic tests of load-bearing piers}

Two of the cyclic tests conducted in the study performed by Costa [2] have been here considered. The analysis conducted on pier 1 , the one with a vertical load of $200 \mathrm{kN}$, presented a rocking failure with a horizontal crack at the bottom part of the masonry wall; such a failure is very similar to the one observed during the tests. Figure 15 displays the cracking paths of specimen 1 at different steps.

The masonry has been modeled using the tensile constitutive law proposed by Hordijk and the parameters are the ones calibrated through the FEM analyses conducted on the vertical, the horizontal and the diagonal compression tests.

(a)

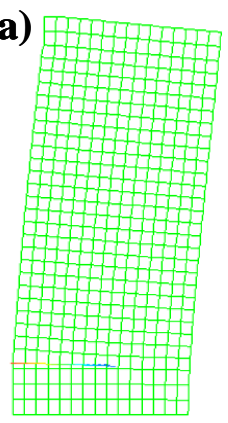

(b)

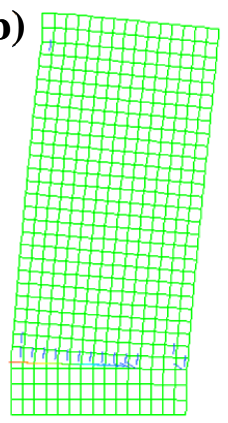

(c)

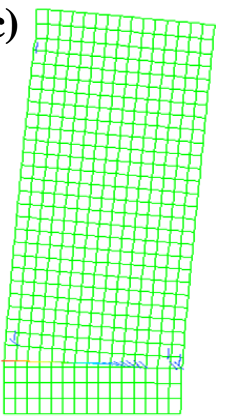

(d)

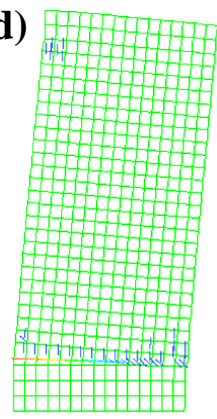

Figure 15: Crack path of specimen 1 at $0.3 \%$ drift (a), $0.45 \%$ drift (b), $0.6 \%$ drift (c) and $0.73 \%$ drift (d).

A comparison between experimental and analysis data highlights a similar overall behaviour; in fact, the stiffness obtained from finite element analysis is very similar to the real one. The maximum force attained is approximately 10\% higher than the experimental one: $54 \mathrm{kN}$ in the FEM analysis and $48.8 \mathrm{kN}$ in the test.

The analysis conducted on wall 2, the one with a vertical load of $300 \mathrm{kN}$, shows a rocking failure with a horizontal crack at the bottom part of the masonry wall and a vertical cracking with a shape similar to a hourglass; also in this case the failure is very similar to the one observed during the tests. Figure 16 presents the cracking path of specimen 2 at different steps.

The results acquired from pushover analysis are capable to predict with enough precision the stiffness, the peak lateral force and the overall behaviour.

The numerical results presented at Figure 17 appear to match accurately the envelope of the experimental ones. 
(a)

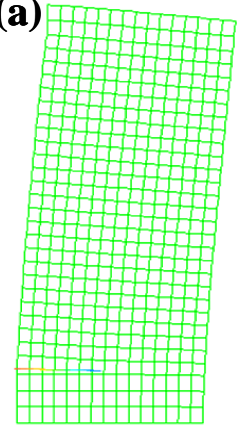

(b)

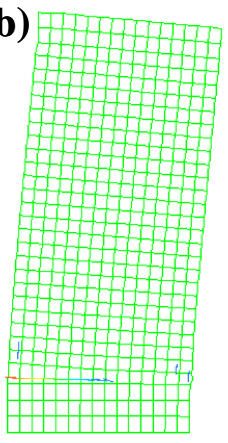

(c)

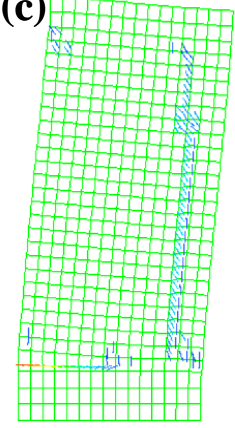

(d)

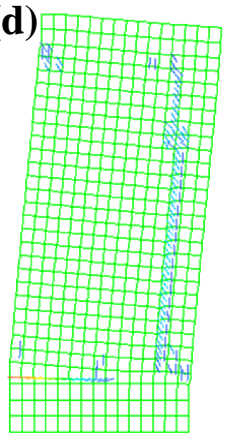

Figure 16: Crack path of specimen 2 at $0.3 \%$ drift (a), $0.45 \%$ drift (b), $0.6 \% \operatorname{drift}(c)$ and $0.73 \%$ drift (d).

(a)

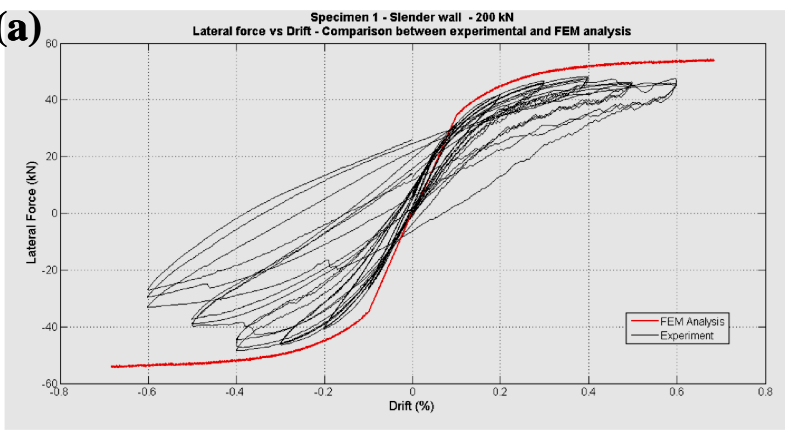

(b)

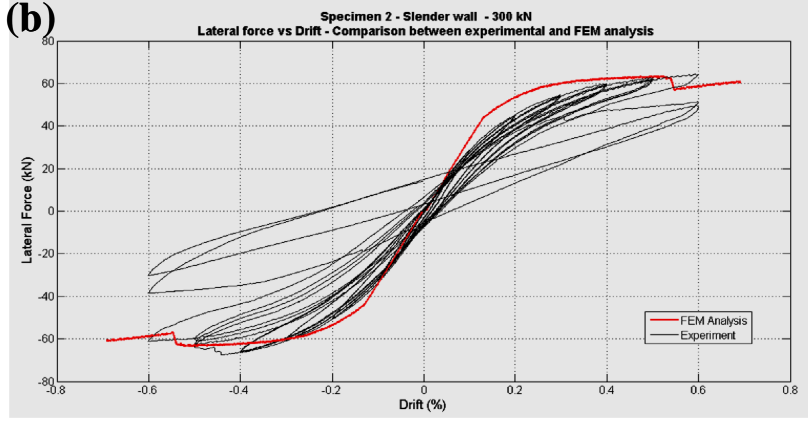

Figure 17: Comparison between the experimental and the pushover analysis results. (a) Specimen 1; (b) Specimen 2.

\section{NUMERICAL SIMULATION OF THE CYCLIC RESPONSE OF A R.C. FRAME WITH AAC MASONRY INFILL}

Nonlinear static FEM analyses of a single bay-single storey r.c. frame without infill and of a fully infilled frame with AAC masonry have been performed, using the parameters of the materials described in Sections 4 and 5.

\subsection{R.c. bare frame}

The test on the single bay-single storey r.c. frame without infill (bare frame) was conducted within the experimental research conducted by Calvi and Bolognini [1] at University of Pavia and described in Section 3.

The in-plane cyclic response of the bare frame has been simulated firstly in order to obtain a reliable finite element model of the $\mathrm{RC}$ frame, and, at a later stage, to study the influence of the masonry AAC infill (see Section 6.2). In fact, it is extremely important to interpret the behaviour of the bare RC frame to better understand the influence of the infill on the structure.

A phased analysis has been performed; firstly the vertical loads were applied, secondly an incremental imposed displacement was imposed (pushover analysis). Four materials have been used according to the characterization material tests: the concrete of the beam, the concrete of the column, the steel of the longitudinal reinforcement and the steel of the transversal reinforcement. According to the reinforcement details, a clear cover of the concrete elements equal to $27 \mathrm{~mm}$ has been used. Only few experimental data on the mechanical characteristics of the concrete were available and, therefore, some values have been assumed making reference to the Eurocode 2 [25] and the CEB FIP 2010 Model Code [26]. The properties of the concrete and of the reinforcement steel used in the FEM model are reported in Table 2. 


\begin{tabular}{|c|c|c|c|c|}
\hline & $\begin{array}{l}\text { Experi- } \\
\text { mental }\end{array}$ & $\begin{array}{c}\text { FEM } \\
\text { analysis }\end{array}$ & \multicolumn{2}{|c|}{ Standards formulae } \\
\hline \multicolumn{5}{|l|}{ COLUMN CONCRETE } \\
\hline Young Modulus [MPa] & --- & 24303 & $\begin{array}{c}0.8 E_{c m}=0.8 \\
22\left[\left(f_{c m}\right) / 10\right]^{0.3}\end{array}$ & $\begin{array}{c}E_{c m} \text { from Table } \\
\text { 3.1 EC2 }\end{array}$ \\
\hline Poisson ratio & --- & 0.2 & 0.2 & $3.1 .3(4) E C 2$ \\
\hline Density $\left[\mathrm{kg} / \mathrm{m}^{3}\right]$ & --- & 2500 & --- & --- \\
\hline Tension Strength [MPa] & --- & 2.307 & $f_{c t m}=0.30 f_{c k}^{(2 / 3)}$ & Table 3.1 EC2 \\
\hline $\begin{array}{c}\text { Tension Fracture Energy } \\
{\left[\mathrm{Nmm} / \mathrm{mm}^{2}\right]}\end{array}$ & --- & 0.0939 & $\begin{array}{c}0.773 f_{c m}^{0.18} \leq \mathrm{G}_{\mathrm{F}}^{\mathrm{I}} \leq \\
1.373 f_{c m}^{0.18}\end{array}$ & CEB FIP 2010 \\
\hline Compression Strength [MPa] & 29.32 & 29.32 & --- & --- \\
\hline \multicolumn{5}{|l|}{ BEAM CONCRETE } \\
\hline Young Modulus [MPa] & --- & 25532 & $\begin{array}{c}0.8 E_{c m}=0.8 \\
22\left[\left(f_{c m}\right) / 10\right]^{0.3}\end{array}$ & $\begin{array}{c}E_{c m} \text { from Table } \\
3.1 \text { EC2 }\end{array}$ \\
\hline Poisson ratio & --- & 0.2 & 0.2 & $3.1 .3(4) E C 2$ \\
\hline Density $\left[\mathrm{kg} / \mathrm{m}^{3}\right]$ & --- & 2500 & --- & --- \\
\hline Tension Strength [MPa] & --- & 2.671 & $f_{c t m}=0.30 f_{c k}^{(2 / 3)}$ & Table 3.1 EC2 \\
\hline $\begin{array}{c}\text { Tension Fracture Energy } \\
{\left[\mathrm{Nmm} / \mathrm{mm}^{2}\right]}\end{array}$ & - & 0.0967 & $\begin{array}{c}0.773 f_{c m}^{0.18} \leq \mathrm{G}_{\mathrm{F}}^{\mathrm{I}} \leq \\
1.373 f_{c m}^{0.18}\end{array}$ & CEB FIP 2010 \\
\hline Compression Strength [MPa] & 34.56 & 34.56 & --- & --- \\
\hline \multicolumn{5}{|c|}{ LONGITUDINAL REINFORCEMENT STEEL } \\
\hline Young Modulus [MPa] & -- & 200000 & 200000 & 3.2.7(4) EC2 \\
\hline Poisson ratio & --- & 0.3 & 0.3 & $3.2 .5(1) E C 3$ \\
\hline Yield Strength $[\mathrm{MPa}]$ & 558 & 558 & --- & --- \\
\hline Ultimate Strength [MPa] & 649 & 649 & --- & --- \\
\hline Ultimate Strain & --- & 0.023 & --- & $3.3 .6(7) E C 2$ \\
\hline \multicolumn{5}{|c|}{ TRANSVERSAL REINFORCEMENT STEEL } \\
\hline Young Modulus [MPa] & --- & 200000 & 200000 & 3.2.7(4) EC2 \\
\hline Poisson ratio & --- & 0.3 & 0.3 & $3.2 .5(1) E C 3$ \\
\hline Yield Strength $[\mathrm{MPa}]$ & 557 & 557 & --- & --- \\
\hline Ultimate Strength [MPa] & 630 & 630 & --- & --- \\
\hline Ultimate Strain & --- & 0.023 & --- & $3.3 .6(7) E C 2$ \\
\hline
\end{tabular}

Table 2: Material properties values used for concrete and reinforcement steel.

Calvi and Bolognini [1] estimated the initial stiffness of the r.c. bare frame equal to 12087 $\mathrm{kN} / \mathrm{m}$. The maximum horizontal force reached in the test, according to the envelope curves, was $227.7 \mathrm{kN}$. As reported in Figure 18a, the pushover analysis conducted on the FEM numerical model has been able to accurately predict the overall response of the bare frame, especially the peak strength (equal to $225.5 \mathrm{kN}$ ) and the post-yielding behaviour. In order to match the results in terms of initial stiffness (in the FEM model equal to $14316 \mathrm{kN} / \mathrm{m}$ ), a value for the Young elastic modulus $E$ equal to $80 \%$ of the average elastic modulus $\left(E_{c m}\right)$ evaluated according to the expressions in the EC2, was used; this approximation is however in line with the common dispersion of the values of this parameter. In Figure 18b, the deformed shape at the last drift (3.6\% drift) has been reported. 
(a)

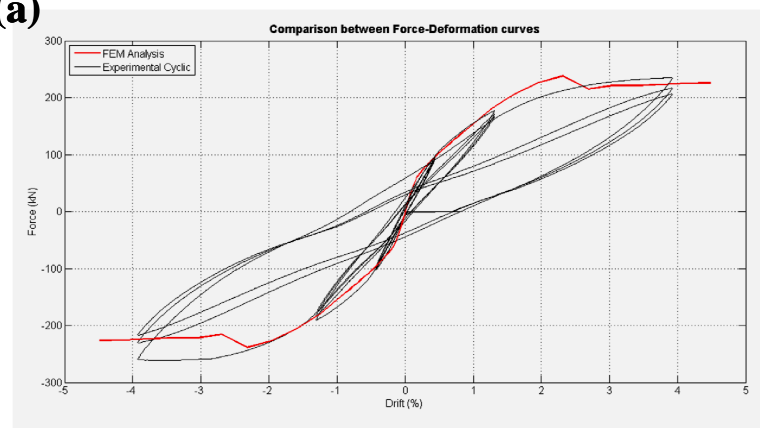

(b)

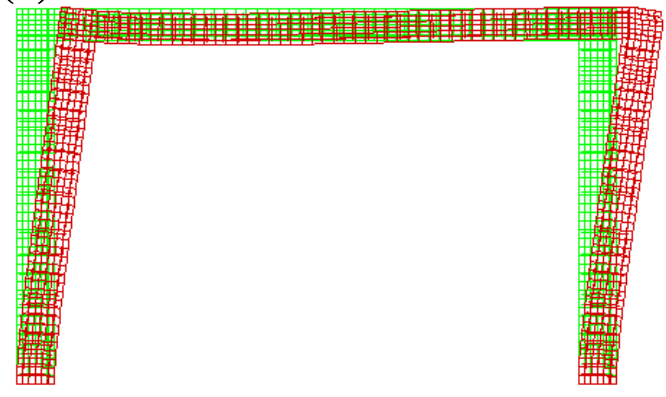

Figure 18: (a) Comparison Force-Deformation curves. Pushover FEM analysis results versus experimental cyclic results. (b) Deformed shape at $4.3 \%$ drift.

\subsection{AAC masonry infilled frame}

The experimental test conducted at the University of Pavia by Penna and Calvi [3] had demonstrated that the masonry infilled frame performed a very different lateral response as respect to the bare frame. A lower maximum drift was reached and the infilled RC frame presented a stiffer behaviour and reached an higher maximum force peak.

The same phased FEM analysis conducted for the model described in Section 6.1 has been here carried out. The material properties of the concrete and of the steel rebars assumed for the bare frame have also been used for this model; in addition, the properties of the interface mortar and of the AAC masonry, calibrated with the simple models described in Section 5, have been considered and reported in Table 3.

\begin{tabular}{|c|c|c|c|}
\hline & $\begin{array}{l}\text { Exper- } \\
\text { imental }\end{array}$ & $\begin{array}{c}\text { FEM } \\
\text { analysis }\end{array}$ & \\
\hline \multicolumn{4}{|l|}{ AAC MASONRY } \\
\hline Young Modulus [MPa] & 1498 & 1498 & From tests of characterization \\
\hline Density $\left[\mathrm{kg} / \mathrm{m}^{3}\right]$ & 484 & 484 & From tests of characterization \\
\hline Tension Strength [MPa] & --- & 0.279 & From tests of characterization \\
\hline Tension Fracture Energy $\left[\mathrm{Nmm} / \mathrm{mm}^{2}\right]$ & --- & 0.0567 & Calibrated on the cyclic test \\
\hline Compression Strength $[\mathrm{MPa}]$ & 2.0 & 2.0 & From tests of characterization \\
\hline \multicolumn{4}{|l|}{ INTERFACE MORTAR } \\
\hline Cohesion $[\mathrm{MPa}]$ & --- & 1.15 & Calibrated on the cyclic test \\
\hline Friction Angle & --- & 0.31 & Calibrated on the cyclic test \\
\hline Tensile Strength [MPa] & --- & 0.10 & Calibrated on the cyclic test \\
\hline
\end{tabular}

Table 3: Material properties values used for masonry and interface mortar..

The experimental secant stiffness calculated at $40 \%$ of the maximum force was 80972 $\mathrm{kN} / \mathrm{m}$, whereas the one obtained from the numerical analysis is $75369 \mathrm{kN} / \mathrm{m}$, whereas the initial stiffness, measured at $10 \%$ of the maximum strength, is $81340 \mathrm{kN} / \mathrm{m}$ and $86551 \mathrm{kN} / \mathrm{m}$ for experimental and FEM analysis, respectively. The maximum strength reached during the test, according to the average envelope, was $439 \mathrm{kN}$ and the horizontal load peak for the finite element analysis is $388 \mathrm{kN}$. However, Figure 19a shows that the results of the FEM analysis are able to accurately predict the overall behaviour of the structure. Figure $19 \mathrm{~b}$ shows how the results of the FEM analysis predicts better the third cycle than the first one, meaning that the assumptions made on the material properties represent appropriate conservative choices. 
(a)

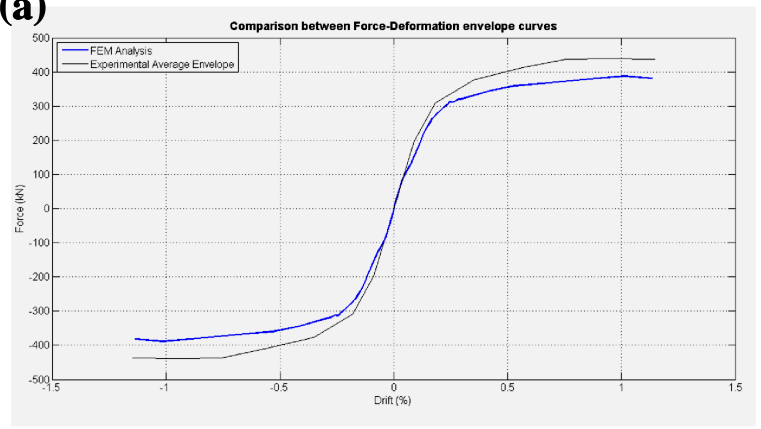

(b)

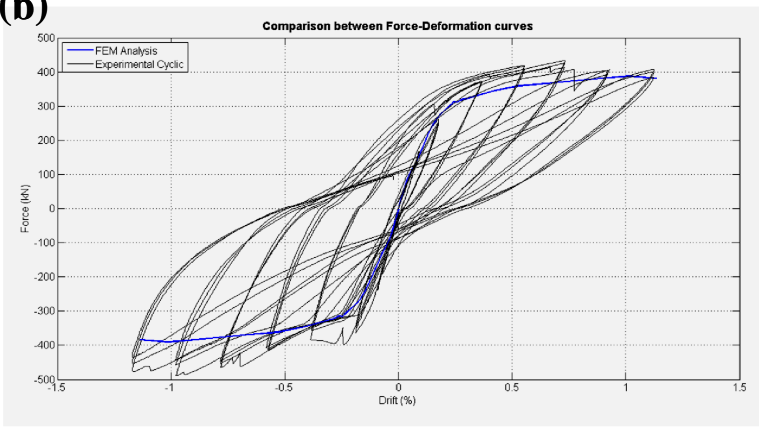

Figure 19: (a) Comparison Force-Deformation: (a) envelope curves; (b) cyclic curve.

Figure $20 \mathrm{a}, 20 \mathrm{~b}$ and $20 \mathrm{c}$ show the crack pattern at $0.40 \%, 0.75 \%$ and $1.10 \%$ drift, respectively.

(a)

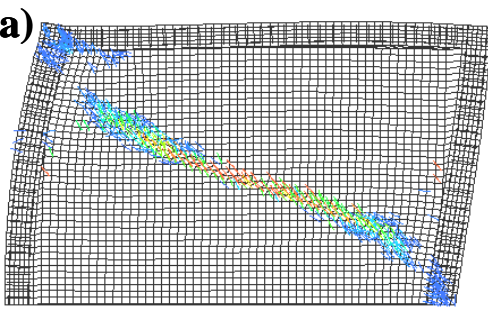

(b)

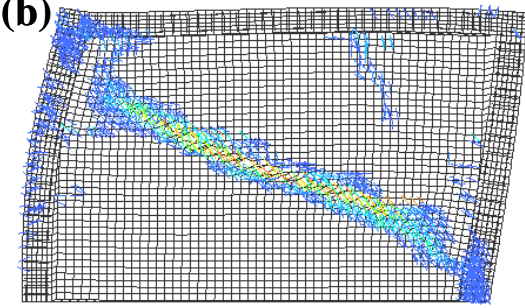

(c)

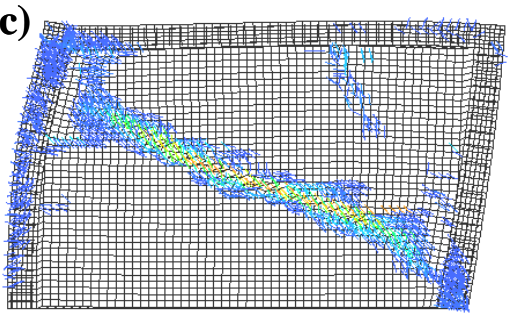

Figure 20: Crack pattern at $0.40 \%$ drift (a); $0.75 \%$ drift (b); $1.10 \%$ drift (c).

Moreover, the numerical simulation has allowed to compare the results in terms of cracking pattern. The results of the analysis appear to be in line to those of the cyclic tests, as reported in Figure 21a in the case of $0.40 \%$ drift. Figure $21 \mathrm{~b}$ shows a comparison between the experimental and analytical crack patterns considering the experimental cracks due to the load applied in the same direction of the pushover analysis. In Figure $21 \mathrm{~b}$ is clearly visible that the results of the FEM analysis is able to capture the main diagonal crack, although it cannot predict in a precise way some of the minor cracks.

(a)

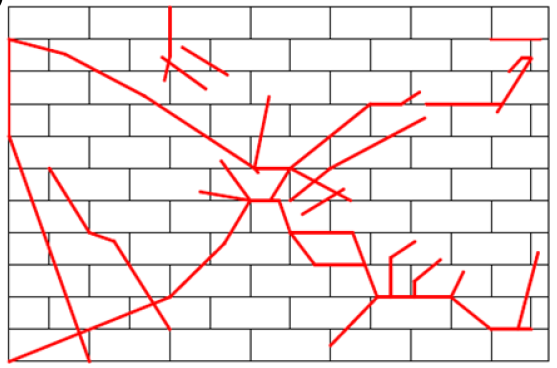

(b)

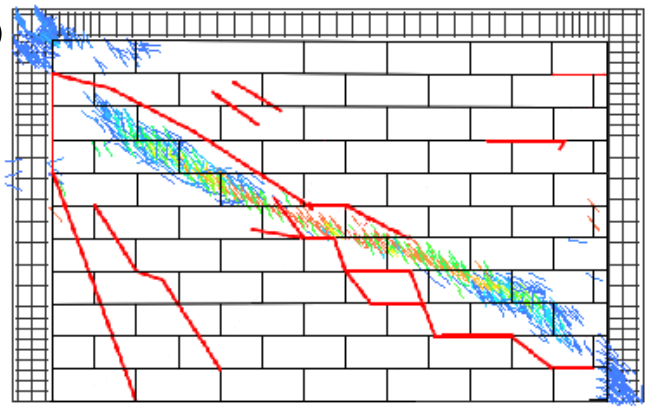

Figure 21: (a) Experimental crack pattern at $0.40 \%$ drift [3]. (b) Comparison between experimental and analytical crack patterns at $0.40 \%$ drift.

\subsection{Effect of the infills on the response of the r.c. frame}

It has been clearly demonstrated, both experimentally and numerically how the global behaviour of the infill can be modified due to the presence of the infill. Figure 23 illustrates the numerical average positive envelope of the Force-Drift curves of the bare and the infilled frame; moreover, the difference between the infilled and the bare frame response has been evaluated and it is reported with the red curve and it represents a simplified way to estimate the infill contribution of the lateral response. The infill contribution $F_{w, h o r}$ at the correspond- 
ing displacement $d_{m}{ }^{\prime}$ to the overall capacity $F_{\max }$ at the displacement $d_{\max }$ has been evaluated subtracting the average force displacement curve of the bare frame from that of the infilled one. Figure 22 sketches the procedure. $F_{\max }$ is the maximum strength reached by the infilled frame, corresponding to a displacement $d_{\max }$, while $F_{w, h o r}$ is the peak horizontal masonry infill strength achieved at $d_{m}^{\prime}$.

It is therefore clearly noticeable the influence of the AAC masonry infill on the overall response of the infilled frame. The peak force of the infill contribution is reached at $0.53 \%$ drift, which corresponds to a complete activation of the strength of the infill.
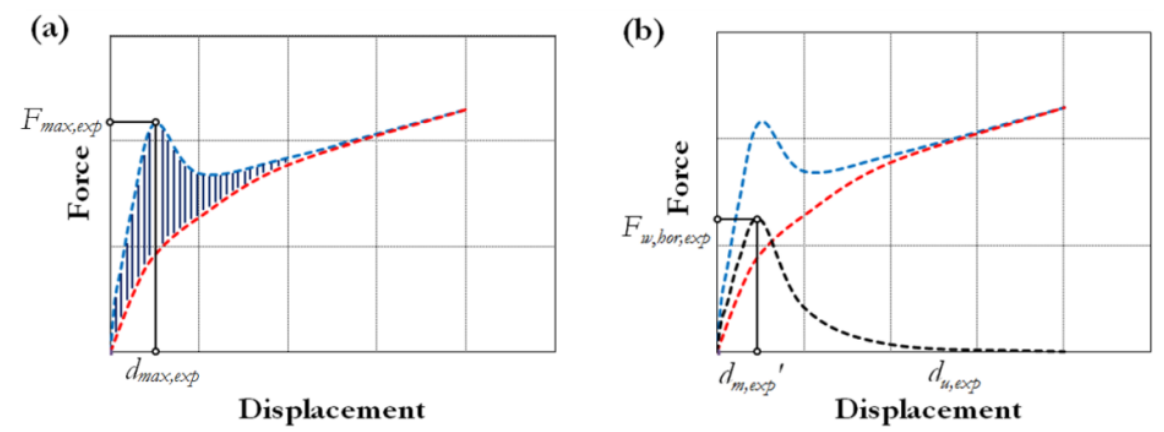

Figure 22: (a) Average capacity curves for bare and infilled frames; (b) Average force contribution of the masonry infill [30].

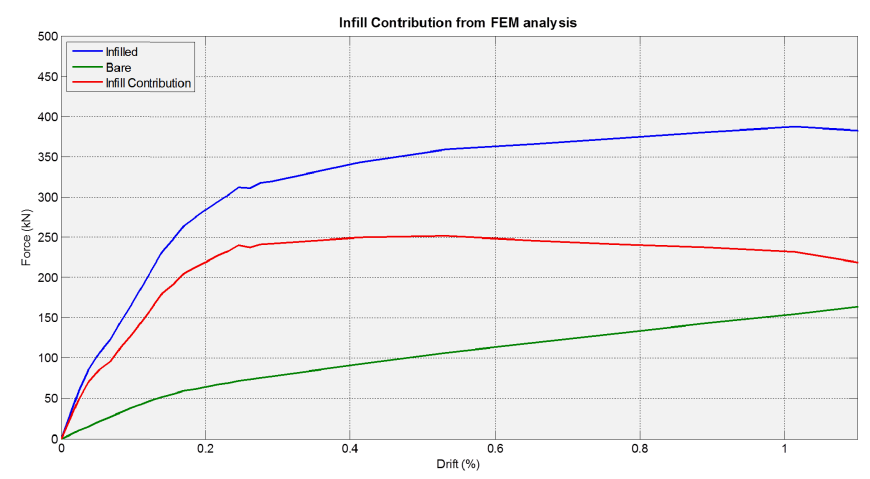

Figure 23: Infill contribution from numerical results.

\subsection{Local effects on the r.c. columns due to the infill}

As reported by Hak et al. [31], the possible occurrence of local effects on structural elements of infilled RC frames with masonry infills is widely recognized and also supported by field evidence from recent earthquakes events. In particular, local damage and eventually brittle failure can commonly be caused on columns which are in partial contact with masonry infill, causing a reduction of the clear height of the column and, hence, inducing locally increased shear and displacement demands. However, detrimental effects on columns of RC frames structures can be caused by the interaction with masonry infills also in the case of full contact along the height of the column, in particular when masonry infill typologies of high strength and stiffness properties are used in construction, and/or when the infill is located only on one side of the column. Specifically, additional concentrated shear demands may be imposed on the column at its ends in the region of contact with the masonry infill due to the activation of compressive diagonal strut forces, possibly causing local column damage or shear failure. Assuming that additional shear is imposed on the columns of the frame due to the activation of a diagonal strut force in the masonry panel, it has to be pointed out that the full 
strut action is achieved only after a certain inter-storey demand has been reached. In Section 6.3 it has been observed that the complete strut activation occurred at $0.53 \%$ drift. Therefore a comparison between bare and infilled frame at $0.53 \%$ drift has been studied. More specifically, Figure 24a and Figure 24b illustrate how the distribution of the bending moment and of the shear of the infilled frame assume different shapes along the height of the column adjacent to the infill as respect to the r.c. column of the bare frame.

(a)

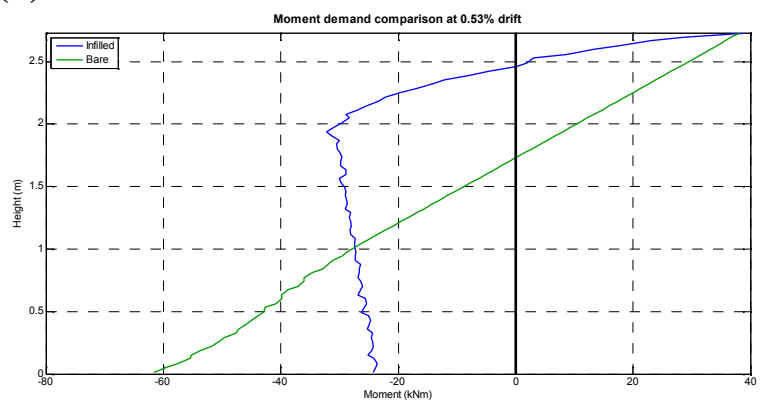

(b)

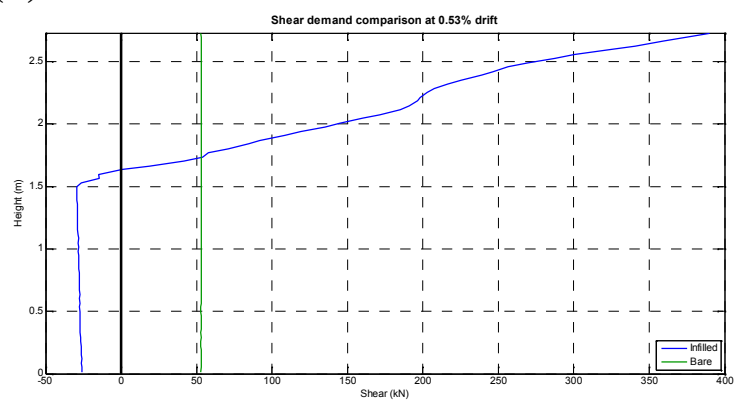

Figure 24: Comparison between bare and infilled r.c frame at $0.53 \%$ drift: (a) moment and (b) shear distribution on the r.c. column.

The contact length corresponds at $1.25 \mathrm{~m}$ (45\% of total height of the column) and it has been computed from the change of the gradient in Figure 24b.

\section{CONCLUSIONS}

In the present work a study about the meso-modeling of an AAC masonry infill has been developed. A numerical calibration according to the tests conducted at the University of Pavia $[1,3]$ has been performed.

Different models based on smeared crack approach, total strain rotating crack model have been carried out. Both masonry and concrete have been modeled using eight-node quadrilateral isoparametric plane stress elements. An isotropic behaviour and, finally, a Hordijk tensile constitutive law have been assumed.

The model developed have been calibrated replicating the characterization tests (vertical, horizontal and diagonal compression of AAC masonry wallets) performed at the University of Pavia. Furthermore, two AAC load-bearing piers have been modeled to refine the calibration conducted on the characterization tests. Different tensile behaviours (Hordijk and elasticbrittle), have been compared and the former is the most suitable for the aim of this work. The modeling of AAC load-bearing masonry walls was able to predict the envelope of the experimental cyclic behaviour, the stiffness, the peak lateral force and the overall behaviour with a good accuracy. Moreover, the obtained numerical failure mode matched the experimental.

The pseudo-static experiments conducted at University of Pavia by Calvi and Bolognini [1] and by Penna and Calvi [3] have been modeled and numerically replicated through some pushover analyses. A good matching of the behaviours of the bare and infilled frames have been observed. A comparison between the experimental and the finite element crack paths has been fulfilled, and also the effects of the infills on the response of the RC frame and the local effects have been taken into account. Thus, the moment, the shear demands and the contact length on the adjacent RC column in case of bare and infilled frame have been evaluated.

One of the main finding of the study is that, using a meso-model for AAC masonry infills and calibrating it according to few characterization tests on masonry wallets and infill-frame interface, it is possible to simulate a full scale in plane cyclic test on a RC frame with AAC infill. This model can also predict the actual moment and shear distribution on the adjacent 
columns which strongly differ from the ones of the bare frame. Thus, also the contact length can be computed starting from the actual shear distribution on the column. Finally, it is noticeable both experimentally and numerically that the masonry infill interacts with the structure and it modifies the behaviour of the frame; therefore different results in term of displacements, stiffness and internal force distribution have been observed.

\section{ACKNOWLEDGEMENTS}

The research upon which this work is carried out at the University of Pavia, EUCENTRE Pavia and Middle East Technical University, and it is sponsored by the Erasmus Mundus Programme. The financial support of this is gratefully acknowledged.

\section{REFERENCES}

[1] G.M. Calvi, D. Bolognini, Seismic response of reinforced concrete frames infilled with weakly reinforced masonry panels, Journal of Earthquake Engineering, 5, 153-185, 1999.

[2] A. Costa, A. Penna, G. Magenes, Seismic Performance of Autoclaved Aerated Concrete (AAC) Masonry: From Experimental Testing of In-Plane Capacity of Walls to Building Response, Journal of Earthquake Engineering, 15, 1-31, 2011.

[3] A. Penna, G.M. Calvi, Campagna sperimentale su telai in c.a. con tamponamenti in Gasbeton (AAC) con diverse soluzioni di rinforzo [in Italian], Experimental Report, University of Pavia, Italy, 2006.

[4] F. Braga, V. Manfredi, A. Masi, A. Salvatori, M. Vona, Performance of nonstructural elements in RC buildings during the L'Aquila 2009 earthquake, Bulletin of Earthquake Engineering, 9, 307-324, 2011.

[5] P. Ricci, V. Manfredi, F. De Luca, G.M. Verderame, $6^{\text {th }}$ April 2009 L'Aquila earthquake, Italy: reinforced concrete building performance, Bulletin of Earthquake Engineering, 9, 285-305, 2011.

[6] G. Magenes, S. Bracchi, F. Graziotti, M. Mandirola, C.F. Manzini, P. Morandi, M. Palmieri, A. Penna, A. Rosti, M. Rota, M. Tondelli, Preliminary damage survey to masonry structures after the May 2012 Emilia earthquakes, v.1, http://eqclearinghouse.org/2012-05-20-italy-it, 2012.

[7] C.F. Manzini, P. Morandi, Rapporto preliminare sulle prestazioni ed i danneggiamenti agli edifici in muratura portante moderni a seguito degli eventi sismici emilani del 2012 [in Italian], v.1, Eucentre, http://eqclearinghouse.org/2012-05-20-italy/, 2012.

[8] L.D. Decanini, D. Liberatore, L. Liberatore, L. Sorrentino, Preliminary Report on the 2012, May 20, Emilia Earthquake, v.1, http://eqclearinghouse.org/2012-05-20-italy-it/, 2012.

[9] A.B. Mehrabi, Behavior of masonry-infilled reinforced concrete frames subjected to lateral loading, PhD Thesis, University of Colorado, USA, 1994.

[10] F.J. Crisafulli, Seismic behaviour of reinforced concrete structures with masonry infills, PhD Thesis, University of Canterbuty - Christchurch, New Zealand, 1997. 
[11] G.M. Calvi, D. Bolognini, Seismic response of R.C. frames infilled with weakly reinforced hollow masonry panels, University of Pavia, Italy, 1999.

[12] F. Da Porto, G. Guidi, M. Dalla Benetta, N. Verlato, Sistemi costruttivi e risultati sperimentali Reluis Research Report [in Italian], Experimental Report, University of Padova, Italy, 2012.

[13] S. Hak, P. Morandi, G. Magenes, Experimental tests on masonry infilled frames, Pavia, Italy, 2013.

[14] K.M.A. Mosalam, Experimental and Computational Strategies for the Seismic Behavior Evaluation of Frames with Infill Walls, PhD Thesis, Cornell University, USA, 1996.

[15] J.M. Leuchars, J.C. Scrivener, Masonry Infill Panels Subjected to Cyclic In-Plane Loading, Bulletin of Nwe Zealand National Society for Earthquake Engineering, 9, 122-131, 1976.

[16] P. Lourenço, An Orthotropic Continuum Model for the Analysis of Masonry Structures, Delft University of Technology, Netherland, 1995.

[17] A. Stavridis, Analytical and Experimental Study of Seismic Performance of Reinforced Concrete Frames Infilled with Masonry Walls, PhD Thesis, University of California, USA, 2009.

[18] J.R. van Noort, Computational Modeling of Masonry Structures, PhD Thesis, Delft University of Technology, Netherland, 2012.

[19] L. Decanini, F. Mollaioli, A. Mura, R. Saragoni, Seismic performance of masonry infilled RC frames, Proc. of the 13th World Conference on Earthquake Engineering, Vancouver, Canada, 2004.

[20] CEN, Eurocode 8 - Design of structures for earthquake resistance, Brussels, Belgium, European Committee for Standardisation, Part 1: General rules, seismic actions and rules for building, 2004.

[21] F.J. Crisafulli, A.J. Carr, R. Park, Analytical Modeling of Infilled Frame Structures - A General Review, Bulletin of the New Zealand Society for Earthquake Engineering, 33, 2000 .

[22] P.B. Lourenço, An Orthotropic Continuum Model for the Analysis f Masonry Structures, Delft, University of Technology, Netherland, 1995.

[23] TNO-Diana, User's Manual - Version 9.4.3, Delft, Netherland, 2010.

[24] J.G. Roots, Computational modeling of concrete fracture, PhD Thesis, Delft, University of Technology, Netherland, 1988.

[25] F.J. Vecchio, M.P. Collins, The Modified Compression-Field Theory for Reinforced Concrete Elements Subjected to Shear, ACI Structural Journal, 83, 219-231, 1986.

[26] R.G. Selby, F.J. Vecchio, Three-dimensional Constitutive Relations for Reinforced Concrete, Technical Report 93-02, University of Toronto, Toronto, Canada, 1993.

[27] D.A. Hordijk, Local Approach to Fatigue of Concrete, PhD Thesis, Delft, University of Technology, Netherland, 1991.

[28] CEN, Eurocode 2 - Design of concrete structures, Brussels, Belgium, European Committee for Standardisation, Part 1.1: General rules and rules for building, 2004. 
[29] CEB/FIP, Model Code 2010, 2010.

[30] CEN, UNI EN 1052-3 - Methods of test for masonry, Brussels, Belgium, European Committee for Standardisation, Part 3: Determination of initial shear strength, 2007.

[31] S. Hak, P. Morandi, G. Magenes, Evaluation of infill strut properties based on in-plane cyclic tests, Gravedinar, 65, 411-422, 2013.

[32] S. Hak, P. Morandi, G. Magenes, Local effects in the seismic design of rc frame structures with masonry infills, 4th ECCOMAS Thematic Conference on Computational Methods in Structural Dynamics and Earthquake Engineering, 2013. 